\title{
Larval Spirurida (Nematoda) from the crab Macrophthalmus hirtipes in New Zealand
}

\author{
František Moravec ${ }^{1}$, Brian L. Fredensborg ${ }^{2}$, A. David M. Latham ${ }^{2}$ and Robert Poulin ${ }^{2}$ \\ ${ }^{1}$ Institute of Parasitology, Academy of Sciences of the Czech Republic, Branišovská 31, 37005 České Budějovice, Czech \\ Republic; \\ ${ }^{2}$ Department of Zoology, University of Otago, P.O. Box 56, Dunedin, New Zealand
}

Key words: Nematode larvae, Ascarophis, larval Acuariidae, intermediate host, crab, Macrophthalmus, New Zealand

\begin{abstract}
Previously undescribed third-stage larvae of two species of Spirurida were found in the haemocoel of the stalk-eyed mud crab Macrophthalmus hirtipes (Heller) (Ocypodidae) in New Zealand. Examinations by light and scanning electron microscopy showed that the larger larvae (about $7 \mathrm{~mm}$ long) belonged to a species of Ascarophis van Beneden, 1871 (Cystidicolidae), the genus including parasites of fishes, whereas the smaller larvae (about 4-5 mm long) belonged to the Acuariidae, a family with species parasitic as adults mostly in aquatic birds. In a sample of 82 specimens of $M$. hirtipes collected in July 2002 from Papanui Inlet, on Otago Peninsula, South Island, 74 crabs $(90.2 \%)$ were infected with larval nematodes with an intensity of 1-18 (mean 4.6) nematodes per crab; no distinction between nematode species was made in these estimates, although juvenile Acuariidae greatly outnumbered larval Ascarophis. Apparently, crabs play a role as intermediate hosts of these nematode species. This is the first record of larval representatives of Cystidicolidae and Acuariidae from invertebrates in the Australasian Region.
\end{abstract}

The order Spirurida includes a large and diverse group of nematodes which use arthropod intermediate hosts. Generally, their infective stage is the third-stage larva developing in the intermediate host, even though several cases of precocious development in the latter were described (see Anderson 2000). The identification of these larvae is usually problematic, because the development and larval morphogenesis of the majority of described species remain unknown.

During recent investigations into the parasites of crabs in southern New Zealand, numerous larval spirurids of two hitherto unknown types were observed in the haemocoel of the stalk-eyed mud crab Macrophthalmus hirtipes (Heller). These are described below.

\section{MATERIALS AND METHODS}

Although the nematode larvae were found as frequent parasites of Macrophthalmus hirtipes from several localities in New Zealand, the specimens used for morphological studies were collected from Papanui Inlet, on Otago Peninsula, South Island, New Zealand, in June 2002. The nematodes were fixed in AFA and cleared with glycerine for examination by light microscopy. Drawings were made with the aid of a Zeiss microscope drawing attachment. After examination, some specimens were transferred to $70 \%$ ethanol for storage. For scanning electron microscopy (SEM), several specimens were placed briefly in $4 \%$ formaldehyde and then postfixed in $1 \%$ osmium tetroxide, dehydrated through a graded alcohol series, critically point dried, and sputter-coated with gold. They were examined with a JEOL JSM-6300 scanning electron microscope at an accelerating voltage of $15 \mathrm{kV}$. All measurements are in micrometres unless otherwise stated. The specimens have been deposited in the helminthological collection of the Institute of Parasitology, ASCR, in České Budějovice.

\section{RESULTS}

Larvae of the following two species of nematodes were found in the stalk-eyed mud crab Macrophthalmus hirtipes (Heller, 1862) (Brachyura: Ocypodidae). Data on infection levels were obtained from a sample of $M$. hirtipes collected in July 2002 from Papanui Inlet, on Otago Peninsula, South Island, New Zealand. Out of 82 crabs examined for parasites, 74 (90.2\%) were infected with larval nematodes. The intensity of infection was 1 to 18 (mean 4.6) nematodes per crab; no distinction between nematode species was made in these estimates, although acuariid larvae greatly outnumbered those of Ascarophis. Since only two specimens of Ascarophis larvae were available to study, several additional $M$. hirtipes from the same locality were recently examined, but these proved to harbour only numerous acuariid larvae. All nematodes were found in the haemocoel of crabs; bodies of Ascarophis larvae were covered by thin, membranous capsules, whereas Acuariidae larvae were free in the host's haemocoel. 
A

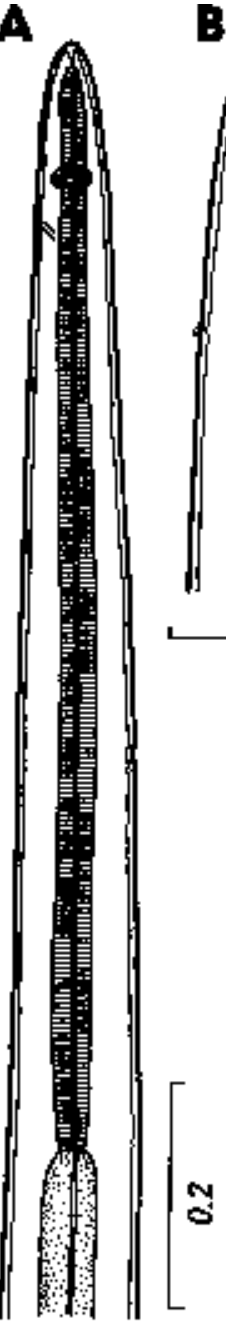

$c$

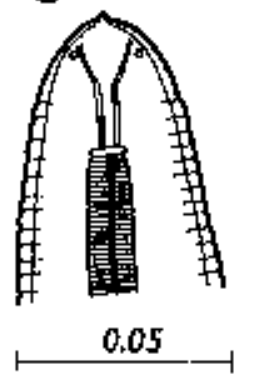

D

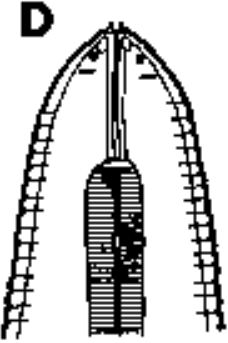

E

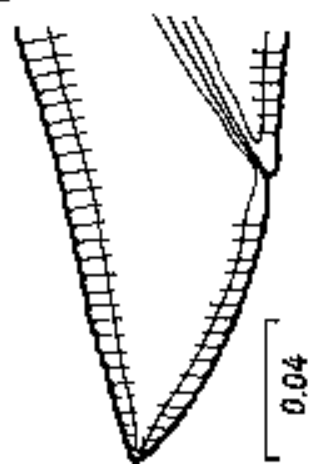

F

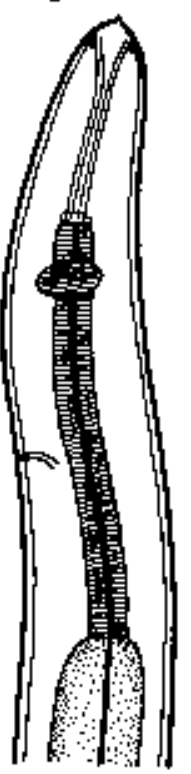

G

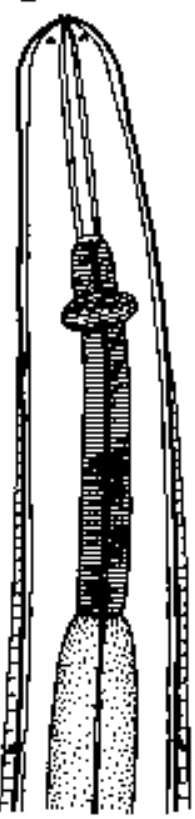

H

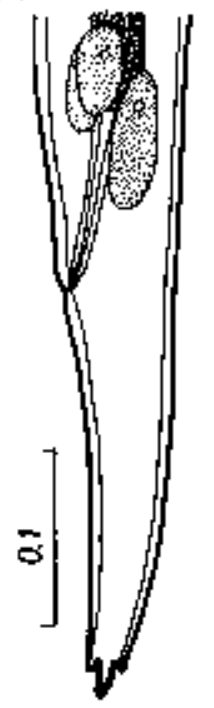

I

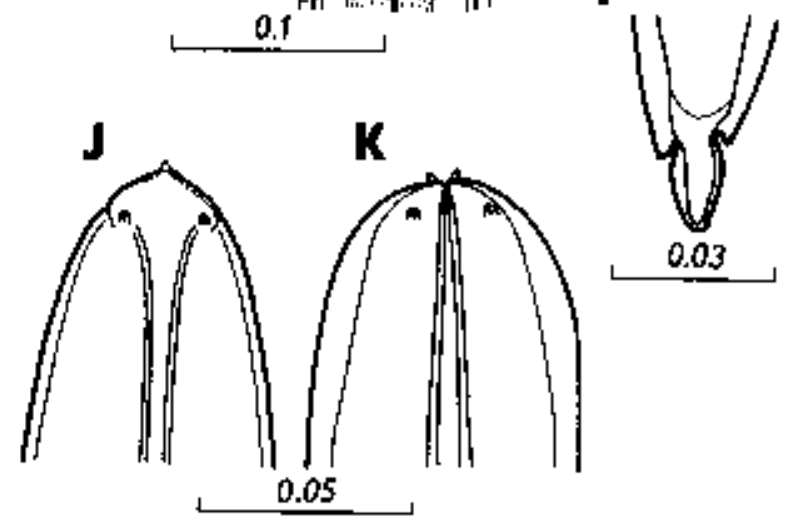

Fig. 1. Nematode larvae from crabs in New Zealand. A-E - Ascarophis sp. third-stage larva (A, B - anterior part of body, lateral and dorsoventral views; C, D - cephalic end, lateral and dorsoventral views; E - tail, lateral view). F-K - Acuariidae gen. sp. third-stage larva (F, G - anterior part of body, lateral and dorsoventral views; $\mathrm{H}$ - tail, sublateral view; I - tail tip, ventral view; J, $\mathrm{K}$ - cephalic end, lateral and dorsoventral views). Scale bars in $\mathrm{mm}$.

\section{Family C y s t i d i c o 1 id a e Skrjabin, 1946}

\section{Ascarophis sp. third-stage larvae}

Figs. 1 A-E, 2

Description (based on 2 specimens): Body elongate, whitish, 7,140 and 7,290 long, maximum width 159 and 171. Cuticle of whole body with fine, dense transverse striations; numerous narrow bands of elevated cuticle oblique to longitudinal body axis visible on anterior part of body (Fig. 2 C). Cephalic end rounded. Oral aperture dorsoventrally elongated, surrounded by four submedian labia and two small lateral pseudolabia. Anterior surface of each pseudolabium bearing small, conical terminal tooth (pseudolabial protuberance according to Ko 1986) (Fig. 2 A). Internally each submedian labium bearing bilobed sublabium (Fig. 2 A). Mouth surrounded by four submedian cephalic papillae and two small lateral amphids (Fig. 2 A). Vestibule (stoma) comparatively short, 33 and 36 long, its anterior end expanded to form distinct funnel-shaped prostom in lateral view (Fig. 1 C). Muscular oesophagus narrow, almost cylindrical, 741 and 1,034 long and 27 wide. Glandular oesophagus distinctly longer and wider, its length 1,469 and 1,632, maximum width 72 and 75 . Length ratio of muscular and glandular oesophagus $1: 1.6$ and $1: 2.0$. Entire oesophagus 2,210 and 2,666 long, representing $31 \%$ and $37 \%$ of whole body length. Nerve ring 114 and 126 from anterior extremity, encircling muscular oesophagus near its anterior end. Small, simple deirids and excretory pore situated short distance posterior to nerve ring, 147 and 177-180, respectively, from anterior extremity. Genital primordium elongate, its middle situated 2,210 and 2,842 from posterior end of body. Tail short, conical, 75 and 78 long, with small knob-like terminal formation. 

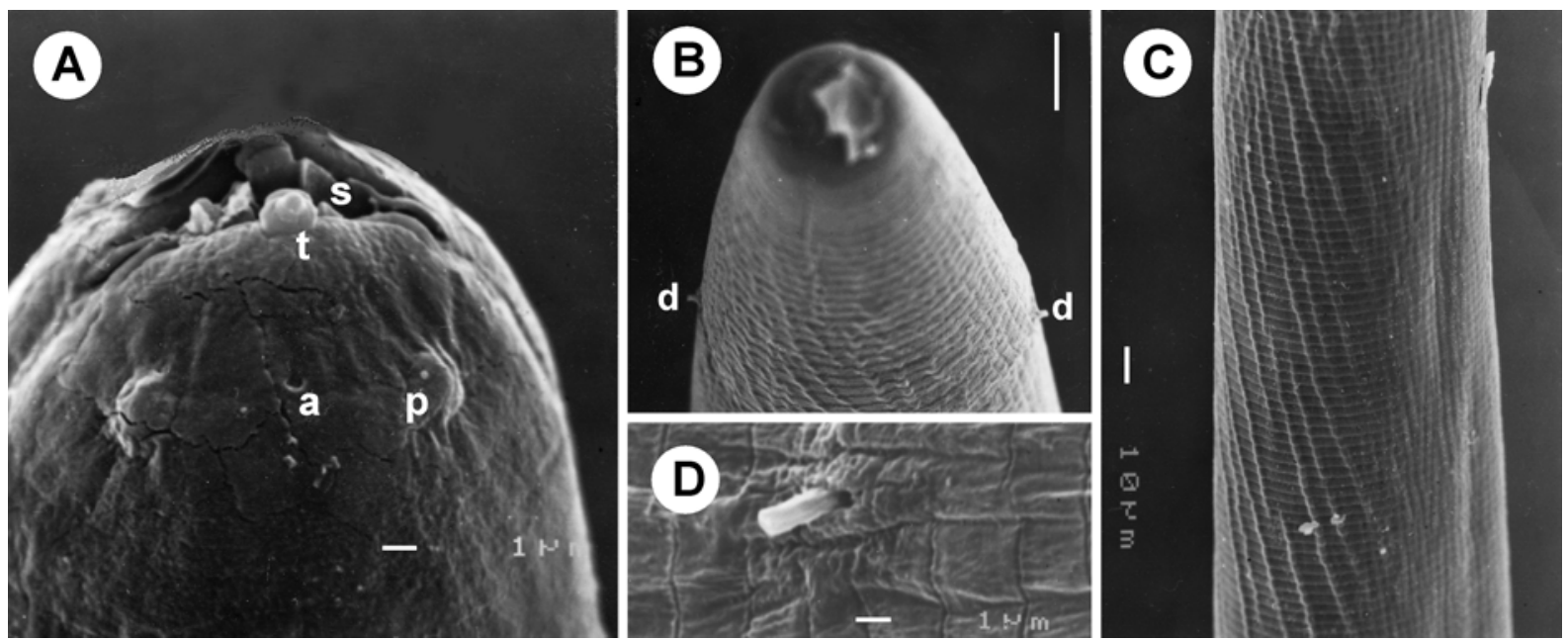

Fig. 2. Ascarophis sp. third-stage larva, scanning electron micrographs. A - cephalic end, lateral view; $\mathbf{B}$ - anterior end of body, ventral view, to show situation of deirids (focused to deirids); $\mathbf{C}$ - region of anterior part of body with distinct oblique bands of elevated cuticle; D - deirid. Abbreviations: a - amphid; $\mathrm{d}$ - deirid; $\mathrm{p}$ - cephalic papilla; $\mathrm{s}$ - sublabium; $\mathrm{t}$ - pseudolabial terminal tooth. Scale bar: $\mathrm{B}=10 \mu \mathrm{m}$.

Family A c u a r i i d a e Railliet, Henry et Sisoff, 1912

Acuariidae gen. sp. third-stage larvae Figs. $1 \mathrm{~F}-\mathrm{K}, 3$

Description (based on 10 specimens): Body elongate, whitish, 4,461-5,222 long and 122-126 wide, with finely transversely striated cuticle. Cephalic end rounded. Oral aperture dorsoventrally elongated, slitlike, surrounded by two large lateral pseudolabia, each with large, conical terminal tooth, and by four submedian cephalic papillae and pair of small lateral amphids situated at base of pseudolabia (Fig. $3 \mathrm{C}-\mathrm{H}$ ). Cuticular cordons present, but distinctly visible only using SEM. Cordons rather long (215-220), originating as submedian at sides of pseudolabia and extending posteriorly to anastomose at their ends. Distance between two anastomosing cordons in their posterior halves gradually narrowing towards their connection and these posterior halves of cordons shifted somewhat dorsally from median line of body (Fig. 3 A). Each cordon consisting of two longitudinal rows of small, sclerotized bilobed plates (Fig. 3 G). Narrow lateral alae initiate at approximately mid-length of cordons (Figs. 1 $\mathrm{G}$ and $3 \mathrm{~A}$ ) and extend posteriorly along almost whole body length. Vestibule (stoma) rather long, measuring 111-135, expanded at its anterior end to form small funnel-shaped prostom in lateral view. Muscular oesophagus short, almost cylindrical, 270-336 long and 2730 wide. Glandular oesophagus broader and much longer, its length 1,686-2,008, maximum width 69-81. Length ratio of muscular and glandular oesophagus 1 : 5.8-6.2. Entire oesophagus 1,956-2,344 long, representing $44-47 \%$ of whole body length. Nerve ring 162 171 from anterior extremity, encircling muscular oesophagus near its anterior end. Deirids small, simple, truncated, situated somewhat posterior to anterior end of glandular oesophagus, 462-517 from anterior extremity (Figs. $1 \mathrm{G}$ and $3 \mathrm{~F}$ ). Excretory pore 285-295 from anterior end of body. Genital primordium 1,292-2,234 from posterior extremity. Tail conical, 190-204 long, provided with one terminal dorsal appendage 12 long and two much shorter subventral appendages (Figs. 1 I and $3 \mathrm{E}$ ).

\section{DISCUSSION}

The genus Ascarophis van Beneden, 1871 includes a large number of species parasitic in the digestive tract of marine and estuarine fishes (Ko 1986). Larvae assigned to A. filiformis Polyansky, 1952 and A. morrhuae van Beneden, 1871 were found by Uspenskaya $(1953,1954)$ in various decapods (Enalus, Eupagurus, Hetairus, Pagurus, Pandalus, Spirontocaris) in the Barents Sea. Later Uzmann (1967) reported Ascarophis larvae from the lobster Homarus americanus from North America (USA). In Europe (Brittany coast, France), Petter (1970) recorded larvae assigned to $A$. morrhuae from the crab Carcinus maenas and an unidentified larva of Ascarophis from a crab found in the stomach of Trigla sp. From several species of crustaceans (Anisogammarus, Idothea, Pagurus) from the littoral zone of Big Shantar Island in the Okhotsk Sea, Tsimbalyuk et al. (1970) reported larvae of $A$. pacifica Zhukov, 1960. Poinar and Kuris (1975) found encapsulated Ascarophis sp. larvae in the shore crab, Hemigrapsus oregonensis, and the porcelain crab, Pachycheles rudis, in California, USA; four types of encapsulated congeneric larvae were reported from decapods (Callianassa, Pagurus, Pachycheles, Pugettia) in California and Washington by 

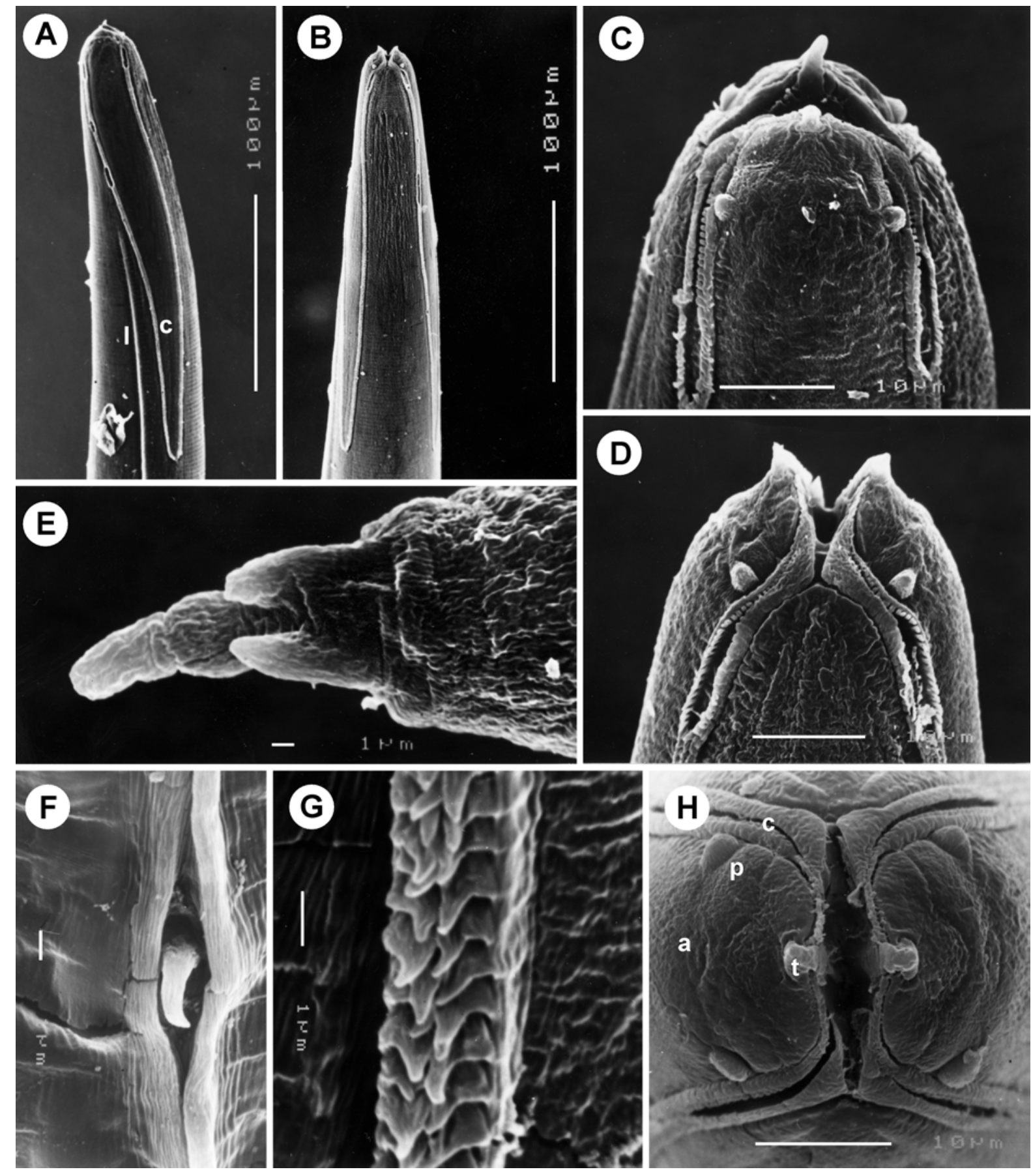

Fig. 3. Acuariidae gen. sp. third-stage larva, scanning electron micrographs. A, B - anterior part of body, lateral and dorsoventral views; C, D - cephalic end, lateral and dorsoventral views; $\mathbf{E}$ - tip of tail, ventral view; $\mathbf{F}$ - deirid; $\mathbf{G}$ - structure of cordon; $\mathbf{H}$ cephalic end, apical view. Abbreviations: $\mathrm{a}$ - amphid; $\mathrm{c}$ - cordon; 1 - lateral ala; $\mathrm{p}$ - cephalic papilla; $\mathrm{t}$ - pseudolabial terminal tooth. Scale bar: $\mathrm{F}=1 \mu \mathrm{m}$.

Poinar and Thomas (1976). Larvae of Ascarophis spp. are known also from amphipods and mysids (e.g., Marcogliese and Burt 1993, Jackson et al. 1997a).

Kulakova and Bityukova (1980) recorded $A$. arctica Polyansky, 1952 and A. morrhuae in three species of gammarids (Gammarus spp.) in the White Sea, where one third of the nematodes found were adults; from gammarids (Gammarus, Marinogammarus) and isopods (Jaera) of the White Sea, A. arctica was also reported by Valter and Valovaya (1987) and Valter (1988). The 
development of Ascarophis sp. (arctica?) in Gammarus oceanicus and Jaera ischiosetosa was experimentally studied by Valter and Valovaya (1990). Adult Ascarophis sp. was also recorded by Appy and Butterworth (1983) from the estuarine Gammarus tigrinus in Canada, by Fagerholm and Butterworth (1988) from Gammarus oceanicus in the Baltic Sea and from Gammarus sp. in northwestern Atlantic in Canada, and by Jackson et al. (1997b) from Gammarus spp. in Quebec, Canada.

The general morphology of larvae in the present material, particularly the structure of the mouth, fully corresponds to Ascarophis (see Ko 1986). Although several types of Ascarophis third- and fourth-stage larvae, including those assigned to A. filiformis, A. morrhuae and $A$. pacifica, were described from crustaceans by the above mentioned authors, the great majority of them distinctly differs from the congeneric larvae from New Zealand crabs in having a markedly longer vestibule (stoma), a relatively shorter muscular oesophagus, and a substantially shorter body length.

In having a very short vestibule, an unusually long muscular oesophagus and a body length about $7 \mathrm{~mm}$, the larvae of the present material somewhat resemble only those described from North American decapods as Ascarophis sp. from Homarus americanus, as Ascarophis sp. from Hemigrapsus oregonensis and Pachycheles rudis, and as Ascarophis sp. A from Callianassa californiensis (Uzmann 1967, Poinar and Kuris 1975, Poinar and Thomas 1976). However, in contrast to the present specimens, all these American forms have the vestibule substantially longer $(52-102 \mu \mathrm{m})$, their muscular oesophagus is distinctly shorter in relation to the length of the glandular oesophagus, and their deirids are situated anterior to the level of the nerve ring (deirids not mentioned in Ascarophis sp. A). Therefore, it is apparent that the New Zealand nematodes belong to an Ascarophis species different from those reported from North American decapods.

Ascarophis larvae from North American decapods were reported to occur in host capsules (Uzmann 1967, Poinar and Kuris 1975, Poinar and Thomas 1976) and the same was observed in congeneric larvae in New Zealand crabs. The oblique bands of elevated cuticle observed by SEM in specimens of the present material may explain that some authors (e.g. Zhukov 1960) reported "spiral striations" on the body surface of some Ascarophis spp.

Crustaceans undoubtedly play a role as intermediate hosts in the life cycles of Ascarophis spp. and, sometimes, these nematodes may even attain sexual maturity in them. Anderson (2000) regards such cases as examples of extreme precocity of a fish nematode in its intermediate hosts.

Hewitt and Hine (1972) listed 12 species of fishes belonging to 7 families that are known to harbour adult Ascarophis nematodes in New Zealand waters.
However, at present it is impossible to assign the larvae from crabs to a certain species of Ascarophis mainly due to inadequate descriptions of many Ascarophis spp. and the fact that apparently many species of this genus from marine fishes have not yet been discovered and described.

Adult nematodes of the Acuariidae are parasitic in the upper alimentary tract mainly of birds, largely those living in aquatic habitats, with only four genera and one species of another genus being found in the stomach of mammals (Anderson 2000). Their life cycles involve various arthropod intermediate hosts; the acuariids which parasitize aquatic hosts develop to the third stage in the haemocoel of aquatic crustaceans (Anderson 2000).

Recently Anderson (2000) gave a review of the known acuariid life cycles, including species of 12 genera, but the larvae from crabs in New Zealand differ considerably in their morphology from all the hitherto described third-stage larvae of this family. Generally, it is believed that cordons are absent from the acuariid third-stage larvae and appear only in conspecific fourthstage larvae, but the larvae reported by previous authors were mostly studied under the light microscope, where the cordons may be indistinct, as shown by the present study.

In some features, the larvae of the present material resemble those in some genera; for example, the presence of lateral alae is also reported for third-stage larvae of Acuaria and Skrjabinocerca and caudal spikelike processes for those of Acuaria and Skrjabinoclava. However, in particular the structure of the tail, posterior situation of deirids, character of the cordons and some other features distinctly differentiate these larvae from those already described. Moreover, the previously described acuariid third-stage larvae are, except for those of Ancyracanthopsis winegardi Wong et Anderson, 1990 , considerably smaller.

Acuariid larvae of only two genera, Skrjabinoclava (S. inornatae Wong et Anderson, 1987) and Ancyracanthopsis (A. winegardi) have so far been recorded from naturally infected crabs in North America (Anderson 2000). In contrast to larvae from New Zealand, those of $S$. inornatae are only $1.2-1.4 \mathrm{~mm}$ long and have a different ornamentation of the tail, whereas those of $A$. winegardi have deirids situated anterior to the level of the nerve ring.

Consequently, at present the species identification of the acuariid larvae from New Zealand crabs is impossible and will depend on subsequent life cycle studies. The definitive hosts of this parasite are probably aquatic birds feeding on the crabs.

Acknowledgements. Thanks are due to the staff of the Laboratory of Electron Microscopy at the Institute of Parasitology, ASCR, České Budějovice, for their technical assistance and D. Frantová and I. Husáková from the Department of Helminthology of the same Institute for their help with the preparation of 
illustrations. This study was partly supported by a grant from the Marsden Fund (New Zealand), and grant no. A6022201 from the Grant Agency of the Academy of Sciences of the Czech Republic.

\section{REFERENCES}

ANDERSON R.C. 2000: Nematode Parasites of Vertebrates. Their Development and Transmission. 2nd Edition. CABI Publishing, Wallingford, Oxon, UK, $650 \mathrm{pp}$.

APPY R.G., BUTTERWORTH E. 1983: Direct development of Ascarophis sp. (Nematoda: Cystidicolidae) in an amphipod. Annual Meeting, Canadian Society of Zoologists, May 15-18, University of Ottawa, Abstracts, p. 37.

FAGERHOLM H.-P., BUTTERWORTH E. 1988: Ascarophis sp. (Nematoda: Spirurida) attaining sexual maturity in Gammarus spp. (Crustacea). Syst. Parasitol. 12: 123-139.

HEWIT G.C., HINE P.M. 1972: Checklist of parasites of New Zealand fishes and of their hosts. N. Z. J. Mar. Freshwater Res. 6: 69-114.

JACKSON C.J., MARCOGLIESE D.J., BURT M.D.B. 1997a: Role of hyperbenthic crustaceans in the transmission of marine helminth parasites. Can. J. Fish. Aquat. Sci. 54: $815-820$

JACKSON C.J., MARCOGLIESE D.J., BURT M.D.B. 1997b: Precociously developed Ascarophis sp. (Nematoda, Spirurata) and Hemiurus levinseni (Digenea, Hemiuridae) in their crustacean intermediate hosts. Acta Parasitol. 42: 31-35.

KO R.C. 1986: A preliminary review of Ascarophis (Nematoda) of fishes. Occasional Publications, Department of Zoology, University of Hong Kong, Hong Kong, 54 pp.

KULAKOVA V.G., BITYUKOVA S.V. 1980: [Littoral gammarids as a source of helminth infections in fishes and birds in the White Sea.] In "Voprosy parazitologii vodnykh bespozvonochnykh", Inst. Zool. Parazitol. AN Lit.SSR, Vilnius, pp. 57-59. (In Russian.)

MARCOGLIESE D.J., BURT M.D.B. 1993: Larval parasitic nematodes infecting marine crustaceans in eastern Canada. 2. Passamaquoddy Bay, New Brunswick. J. Helminthol. Soc. Wash. 60: 100-104.

PETTER A.-J. 1970: Quelques spirurides de poissons de la région nantaise. Ann. Parasitol. Hum. Comp. 45: 31-46.

POINAR G.O. Jr, KURIS A.M. 1975: Juvenile Ascarophis (Spirurida: Nematoda) parasitizing intertidal decapod Crustacea in California: with notes on prevalence and effects on host growth and survival. J. Invertebr. Pathol. 26: $375-382$.

POINAR G.O. Jr, THOMAS G.M. 1976: Occurrence of Ascarophis (Nematoda: Spiruridea) in Callianassa californiensis Dana and other decapod crustaceans. Proc. Helminthol. Soc. Wash. 43: 28-33.

TSIMBALYUK E.M., KULIKOV V.V., TSIMBALYUK A.K. 1970: [On the intermediate hosts and the larval morphology of Ascarophis pacificus (Nematoda, Ascarophididae).] Zool. Zh. 49: 1874-1875. (In Russian.)

USPENSKAYA A.V. 1953: [Life cycle of the nematodes belonging to the genus Ascarophis van Beneden.] Zool. Zh. 32: 828-832. (In Russian.)

USPENSKAYA A.V. 1954: [The parasite fauna of deep water Crustacea in East Murmansk.] Tr. Problem. Temat. Sovesch. Zool. Inst. AN SSSR 4: 123-127. (In Russian.)

UZMANN J.R. 1967: Juvenile Ascarophis (Nematoda: Spiruroidea) in the American lobster, Homarus americanus. J. Parasitol. 53: 218.

VALTER E.D. 1988: [Jaera albifrons (Crustacea, Isopoda), a new host of spirurid nematodes of the genus Ascarophis.] In "Tezisy dokladov III Vsesoyuznoy konferentsii po morskoy biologii”, Izd. INBYuM, Sevastopol, Part 2, pp. 52-53. (In Russian.)

VALTER E.D., VALOVAYA M.A. 1987: [Peculiarities of the life cycle of Ascarophis arctica (Polyansky, 1952), a parasite of gammarids in the White Sea.] In "Problemy izucheniya, ratsionalnogo ispolzovaniya i okhrany prirodnykh resursov Belogo morya", Abstracts of Papers of the 3rd Regional Conference, Kandalaksha, Part 1, pp. 134135. (In Russian.)

VALTER E.D., VALOVAYA M.A. 1990: [Experimental confirmation of the participation of crustaceans in the life cycle of the nematode Ascarophis sp. (arctica?).] In "Morfologiya i ekologiya parazitov morskikh zhivotnykh", Kolskiy Nauch. Tsentr AN SSSR, Apatity, pp. 33-48. (In Russian.)

ZHUKOV E.V. 1960: [Endoparasitic worms of fishes from the Japan Sea and the South-Kurile shallow waters.] Tr. Zool. Inst. AN SSSR 28: 3-146. (In Russian.)

Accepted 28 February 2003 